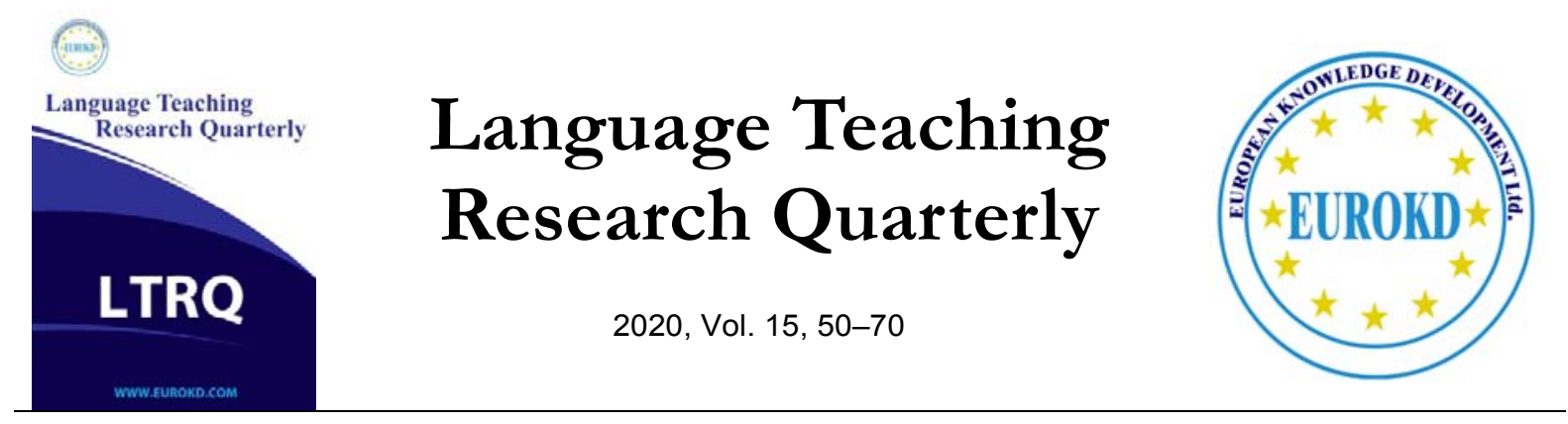

\title{
Gender Representation in Iranian High School Textbook Images
}

\author{
Mohammad Taghei Azad \\ Lecturer, Arak University, Dept. of English Language and Literature Arak, Iran
}

\begin{abstract}
Future Perspectives and Challenges of Materials Development In Honor of Brian Tomlinson's Contribution to Materials Development Research
\end{abstract}

Received 11 August 2019 Accepted 28 November 2019

\begin{abstract}
Many studies have investigated how genders were represented in ELT textbooks. A critical part of ELT textbooks are their images, and how they reflect their authors' ideologies have been the subject many studies. In an attempt to contribute to this line of research, the present study aimed to analyze gender representation in the images of the nation-wide ELT textbooks in Iran called Prospect 1, 2, and 3. Developing a converged framework by utilizing the principles and criteria presented for image analysis in Goffman (1979) and Kress \& van Leeuwen's (2006), the roles of both sexes were analyzed in terms of the active role, gaze direction, visual techniques, distance, and space illustrated in the images of the textbooks. The pictures were analyzed through content analysis and social semiological analysis, and Chi-square analysis indicated that the results of the study were statistically significant. The study found that in the images of the analyzed textbooks, males were depicted as playing a more active role and females were mostly portrayed as the reactive and goal participants. Also, the analysis of gaze direction revealed that males were frequently imaged as looking at the viewer while females were mainly illustrated as looking away from the viewer. Likewise, although women were typically shown in long shot frames - which expands the social distance between the participants in the images and the viewers of the images, men were frequently depicted in close-up frames - which implied their prominence. In contrast, on the subject of clothing, both males and females were portrayed as fully clothed in virtually all pictures of the textbooks, and women were never represented scantily or partially clothed. Concerning the places in which both sexes were portrayed in the images of the textbooks, it was shown that the authors illustrated a rather balanced view towards both males and females. Such a representation of genders in the Prospect Series textbook were discussed to be in line with the Islamic beliefs and culture dominant in Iran, but not consistent with the significant social roles both men and women play in the Iranian society.
\end{abstract}


Keywords: Gender, Gender Representation, Textbook Analysis, Content Analysis, Image Analysis

\section{Introduction}

Numerous studies investigating the role of gender as an influential societal and cultural factor have found that gender is an integral part of our identity and culture which can affect different aspects of our lives, including our social and verbal behavior, self-image, ideologies, and interpersonal attitudes (Cameron, 1998; Christie, 2000; Cunningham, 2008; Del-TesoCraviotto,2006; Erden, 2009; Kendall, 2004; Kuo, 2003; Ladegaard, 2010; Ohara \& Saft, 2003; Pizzini, 1991; Ottley, 2017; Tanaka \& Fukushima, 2002). Yet, there has always been a propensity for gender stereotyping and gender bias which has been displayed in such diverse domains of people's social life as education, family, architecture, workplace conditions, politics, and business (Skliar, 2007; Visser,2002). Lakoff (1973) was a, if not the, pioneer to propose the notion of equal gender awareness in societies. He pointed out that women were more likely to be in lower-status positions than men. In the same vein, Fairclough (1989) articulated that such a relation is also represented in images, averring that "not all photographs are equal: any photograph gives one image of a scene or person from among the many possible images. The choice is important, because different images convey different meanings" (p. 52). Discussing the bias regarding some minority groups and/or women in learning materials, McDonough, Shaw, and Masuhara (2013, p. 58) also pronounced that "the content of some materials will cause offence to some learners".

Taking all such facts into account, therefore, it can be supposed that images can both represent and transfer gender roles, stereotypes, social behaviors, cultural ideologies, and interpersonal attitudes to the people who are exposed to, and ELT/ESL textbook images are of no exception (Fatemi, Pishghadam \& Heidarian, 2011; Giaschi, 2000; Healy, 2009; Kobia, 2009; Paivandi, 2008; Tiemensma, 2009). Moreover, according to Mukundan, Nimechisalem, and Hajimohammadi (2011) and Tomlinson (2011), textbooks in language education can significantly affect students' success or failure. Furthermore, as Riazi (2003) puts forward, "because of the high exposure to textbooks that students experience, care should be taken with regards to any kind of bias or possible destructive elements that might be found"(p.52). Hence, it is recommended to pay a careful attention to how the sexes are represented in the artwork and texts of the textbook materials (Blumberg, 2007; Harwood, 2014; McGrath, 2004; Mishan \& Timmis, 2015; Masuhara \& Tomlinson, 2008). It is also encouraged that gender representation and unbiasedness be included as one of the principles and criteria in textbook pre-, whilst-, and post-use evaluations (Tomlinson \& Masuhara, 2018). In view of that, the present study was conducted to contribute to this line of research by analyzing how male and female characters are represented in the images in 3 nation-wide ELT textbooks prepared by the Iranian Ministry of Education to be used for teaching English to the Iranian students at the first, second, and third grades of high school.

\section{Literature Review}

The review of literature is divided into two subsections: studies on gender representation in 
non-Iranian/global ELT textbooks, and those on gender representation in Iranian ELT textbooks. Both subsections will follow a chronological order so one can have an in-depth understanding of the sexes are represented in the illustrations and texts in different ESL/ELT textbooks materials around the globe.

\section{Studies on Gender Representation in Non-Iranian/Global ELT Textbooks}

A number of studies focused on gender representation in different international ELT/ESL textbooks. In 1976, Goffman, although not directly related to teaching materials, was the first to provide a general theory of gender differences and to apply that theory to the advertising imagery. Using an analytical framework with such dimensions as gaze, body display, modality, and body display, he analyzed the images of the advertisements in which women were portrayed, and tried to decipher the ideologies behind the images in the advertisements. He maintained that women were displayed as submissive, subordinate, having less power than men, being dependent on men, and having the role of bread takers whereas men were usually publicized as breadwinners. By the same token, Gershuny (1977) studied sexism in terms of omissions and commissions in dictionaries and texts and found that women experience much lower visibility than men in the analyzed books. Hartman and Judd (1978) also reported the same results, studying sexism and TESOL materials. Later in 1984, Porreca examined sexism in 15 best-selling ESL materials of the time in the United States, concentrating on such categories as "omission in text and illustrations, firstness, occupational visibility in text and illustrations, nouns, masculine generic constructions, and adjectives" (p. 705). She concluded that, just like what Hartman and Judd (1978) mentioned, women were still portrayed or mentioned "only half as often as males in both text and illustrations" in the US textbooks (p.719). Moreover, Alrabaa (1985) found that the Syrian school textbooks depicted the males as conducting actions like decision-makings while the females were portrayed in the background, ignored and oppressed.

In the1990s, Crabb and Bielawski (1994) investigated the social representation of material culture and gender in children's books in the United States; Skelton (1997) studied gender issues in reading schemes in the United Kingdom; and, Jassey (1998) inspected gender in elementary school texts in Japan, all of which reported stereotypical and underrepresentation of the females. Mirza (1999), conducting a review of the primary school textbooks in Pakistan, concluded that female characters were in the images were portrayed in activities like cooking and doing the household chores, which do not necessitate creative potentials of individuals. The males, however, were depicted in such power-oriented activities as fighting wars, boating, flying, driving, and selling (cited in Mirza, Keynan, \& Fakhar-ud-din, 2004). In the same year, Cortazzi \& Jin (1999) took textbooks in language education and the images in them into account and considered textbook images as a significant channel of both input and ideology for language learners.

Upon the advent of the twenty first century, Giaschi (2000) examined gender representation in Headway series and 4th Dimension, critically analyzing the images in these textbooks to 
find the stereotypical ideologies of gender. The results of his study demonstrated that men were given an active role in the images whereas women were mostly passive in the images, and they were presented a submissive, weak and dependent. In 2001, Sano, Iida, and Hardy investigated gender representation in five series of high school English textbooks in Japan and found that despite any evidence in linguistic features, the textbooks illustrated gender biased messages. They, for instance, reported the textbooks to show the male characters as engaged in actions and decision- makings while there were no such roles considered for the females. Still in Japan, Nakamura (2002) inspected the women's images in the literary stories of Japanese ELT textbooks for high school students. The results of the study indicated that at least $80 \%$ of the stories depicted the men as warm-hearted and having self-control while the women were displayed as emotional, sad, guilty, and even foolish. Another study by Yi (2002) reported similar results. Likewise, Oyebela (2003) investigated the gender representation in the illustrations of a range of upper primary school textbooks in Nigeria and found gender imbalance quite common in those materials. In the same year, Dominguez (2003) contended that language learners can absorb personal biases and cultural prejudice presented in the textbooks. Another study by Liao and Huang (2003) probed gender equality in primary school children ELT textbooks in China, using dialogue content analysis. The results of the study indicated that gender was, remarkably, equally presented in such aspects as turn initiation and conversation dominance, with the exception of using third-person singular pronouns which maintained a bias towards the males. By the same token, Mirza et al. (2004) revealed many cases of gender bias in Urdu and English Language textbooks in Pakistan, and suggested that the textbook materials have "equal representation of male/female roles, include more female role models, and increase the ratio of young women roles" (p.71).

It was in the second half of the 2000s when Stockdale (2006) scrutinized gender representation in a textbook entitled Impact Values in terms of such categories as visibility (characters, appearance in photographs, textbook themes), firstness (in dialogues, points of view opinion, common noun pairs and pronoun pairs, proper name pairs), nouns, and discourse (amount and type of talk). The results of her comprehensive analysis indicated a gender-biased representation of males and females, with men outperforming women and being more visible in almost all the categories of the study. In another study, Lee (2006), comparing the representation of women in textbooks published in 2005 with the same series published in 1988 , revealed that there were more gender equity in the new textbook series than the previous editions. In the same vein, Chick (2006) analyzed gender balance in K-12 American history textbooks and concluded that male figures were more numerous than the female ones in both texts and images.

In Hong Kong, Mineshima (2008) tried to determine how an ELT textbook presently used in upper secondary English classes depicted males and females. The results of the study showed a fair representation of both genders in respect of gender visibility, character attributes, and picture representations. Still, another study by Mukundan and Nimehchisalem (2008) endeavored to depict the representation of genders in Malaysian secondary schools English 
language textbooks, and found an absolute gender bias in the textbooks, with males outnumbering females. On the other hand, applying Sinclair and Culthard's analysis of discourse, Healy (2009) inspected Touchstone Book 2 to decide whether there were any differences in the speech patterns of female and male participants, and revealed an egalitarian representation of both genders in terms of the amount of talk, moves, and firstness. Nevertheless, very different results were reported by Kobia (2009) when he examined the portrayal of gender images in primary school English textbooks in Kenya. The findings of his study showed that females were under-represented in authorship, editorship and typesetting, and that males outnumbered the females in the characters depicted in illustrations, photographs, names and titles. Likewise, Hamdan and Jalabneh (2009), conducting a content analysis on the dialogues and reading passages of the Action Pack Series in Jordan, came to the conclusion that males were mostly presented as the main character in the textbooks. In the same vein, Lee and Collins (2009) explored the degree of gender stereotyping in Australian ELT textbooks and found that men and women were harmoniously displayed in the content and images of the analyzed textbooks.

Early 2010s looked pretty much better than it did in the second half of the 2000s in terms of a steady growth in research on gender representation in textbooks all around the world. For example, Levine and O'Sullivan (2010), using both quantitative and qualitative analyses, investigated gender bias and female invisibility in the illustrations of the Japanese ELT university textbooks, and revealed that males dominated the social roles whereas females were simply depicted as schoolgirls in low-status occupations. In the same year, Kõzõlaslan (2010) conducted a textbook evaluation by attaining senior English language student teachers' perceptions of particular "gender-critical points" in primary level ELT textbooks. Through a survey, the participants were asked two open-ended questions supplemented by focus group interviews. The results indicated that ELT textbooks with sex-stereotypes may have a profound impact on young people's affective and cognitive development, and that it is important for teacher educators to deal with gender biased texts in materials selection, evaluation, design and use. By the same token, Ifegbesan (2010) conducted an evaluation on the post-primary school teachers' gender-stereotyped beliefs and perceptions in classroom practices in Nigeria. Taking the results into consideration, he suggested that in teacher education courses, teachers need to be provided with opportunities to become aware of gender sensitivities. Söylemez (2010) also inspected how social gender identity was constructed in the reading passages in Face 2 Face and English File, elementary, pre- intermediate, intermediate and upper-intermediate textbooks. Scanning the reading texts for the adjectives used to describe both genders, she tried to determine the characteristics attributed to males and females. She found out that the writers of these textbooks had a propensity toward using some adjectives with one gender rather than with the other. In 2012, Atay and Danju studied the stereotypical representations of gender in the primary 1st and 5th grade school textbooks used in Turkish Republic of Northern Cyprus (TRNC) and how they matched with students' views. To do that, they judiciously read the textbooks to explore any gender stereotypical representations and used a questionnaire to 
perceive the students' view about the gender roles related to personality traits. The results of the analysis of images in the textbook were akin to those of the questionnaire with females being regarded as weak (dependent, passive, emotional, sensitive, sad) and males as strong and powerful (brave, active, rich, hardworking, aggressive). Likewise, Saarikivi (2012) examined gender representation in two Finnish ELT textbook series and found gender bias in the analyzed textbooks, which again was in agreement with the hegemonic ideas of gender in the Finnish society.

Mutekwe and Modiba (2012) also investigated gender sensitivity in secondary school textbooks in Zimbabwe along with a focus group interview with a purposive and gender stratified sample of students. They revealed that the analyzed textbooks were gender-biased and embodied innumerable patriarchal values and ideologies. In addition, the interview results of the study indicated that students were pretentious to gender representations demonstrated in the textbooks. Moreover, Alemi and Jafari (2012) also analyzed gender and cultural origin of personal proper nouns in 10 ELT textbooks and found that females were underrepresented in these textbooks. In the same vein, Gholami and Arashlou (2014), examining two global textbooks Top Notch $2 B$ and Interchange Intro, discovered that Top Notch $2 B$ carried gender imbalance regarding the interests, activities, and family roles, and Interchange Intro was gender-biased in terms of genders' occupational roles. in the same line of research, Amerian and Esmaili (2015) studied gender representation in the international American Headway Student Textbook series on the subjects of female's and male's characters, social roles, domestic roles, semantic roles, titles, order of appearance, masculine generic construction, activities, and pictorial representation, and discovered that the series carried both overt sexism, which vividly discriminated against females, and covert sexism, where women were misused as an instrument to promote marketing of the product.

\section{Studies on Gender Representation in Iranian ELT Textbooks}

Ansary and Babaii (2003) were the first to analyze two Iranian nation-wide ELT textbooks, Right Path to English I \& II in terms of such sexist issues in ELT materials as (a) sex-linked job possibilities, (b) sex-related activities, (c) stereotyped sex roles, (d) firstness, and (e) masculine generic conception. To that purpose, they used both a systematic quantitative content analysis and a qualitative inquiry. The results of the study specified that the textbooks analyzed could be considered as sexist since they demonstrated a biased picture of women, with the prevalence of men-oriented topics and females being portrayed in indoor inactive roles.

In 2008, Paivandi conducted a thorough analysis of the Iranian textbooks in ELT and other fields like literature and Islamic Culture and Religious Studies. He found a drought of women in images associated with work and other social roles in a way that women were depicted only in $10 \%$ of work-related images; while the percent of presence in the images was $71 \%$ for men and $19 \%$ for both men and women. Similarly, women were shown only in $5 \%$ of the images representing social activities; notwithstanding the fact that men were presented in $60 \%$, and 
both men and women were portrayed in $35 \%$ of the images). According to the author, such figures echoed the male-oriented nature of Iranian primary and high school textbooks. Moreover, juxtaposing male and female images with lesson topics disclosed that although men were represented as concomitant of social activities in the images, women were mainly displayed in family issues. Moreover, the results of the image analysis showed a limited scope of women's presence in such aspects as workplace, education, and family.

In the same way, Bahman and Rahimi (2010), using both linguistic and content analyses, investigated gender representation in 3 volumes of ELT high schools textbooks in Iran. They examined the textbooks in terms of 1) the frequency of names, nouns, pronouns and adjectives attributed to women and men, 2) first-place occurrences in instructions, exercises and sentences, 3) reading passages to find whether women and men appeared more or less equally or not, 4) male-generics, and 5) animals. They concluded that men were more accentuated than women on the subject of names, nouns, pronouns and adjectives attributed to them. In addition, taking firstness into account, the terms related to male characters came first more frequently than those of the female ones. Moreover, in reading passages, males turned out to be mentioned more frequently than females. Furthermore, women were found to be mostly invisible in these textbooks which were comprised of a great deal of male-generics. Still, even animals were detected to be represented with sexism.

Analyzing Iranian high school and pre-university ELT textbooks both qualitatively and quantitatively, Fatemi et al. (2011) studied verbal and pictorial elements of the textbooks via Rifkin's (1998) model. The results of the analysis based on the Rifkin's model indicated that although women were depicted in traditional and stereotypical roles with weak and secondary nature, sometimes even with no names, men were portrayed in the foreground, with best kinds of adjectives, adverbs, and occupation names. Hence, imbalanced representation of males and females, males outnumbering females in the images of the textbooks, and the failure of the textbooks to mirror the wide range of professional roles women play in the Iranian society were among the most significant findings of the study. The authors (p.42) concluded that such a weak representation of women in the Iranian ELT textbooks can be due to "the subordinate status given to women in context of instructional materials".

In another study, Gharbavi \& Mousavi (2012) analyzed gender bias in four ELT textbooks taught at high schools in Iran. They also revealed that women were less visible than females both in texts and images, and that the textbooks represented males as being more engaged in diverse occupational roles than females. By the same token, Birjandi and Amini (2012) confirmed that Iranian high school ELT textbooks taught for the second and third grades suffered from sexist language, both linguistically and visually, apropos such categories as omission, firstness, masculine generic constructions, occupations, and activities. In the same line of research, Roohani and Zarei (2013), using content analysis, inspected gender representation in Iranian pre-university ELT textbooks and discovered some significant traces of sexism concerning the use of linguistic male-oriented features in names, nouns, and firstness. The results of study revealed a significant gender bias in pictures of the textbook, 
with males being depicted in $100 \%$ of the pictures in volume 1 and $70.58 \%$ of the pictures in volume 2 of the textbook while females were portrayed in none of the pictures of volume 1 and in $29.41 \%$ of the pictures in volume 2 of the textbook.

In 2014, Marefat and Marzban used Halliday's (1994) social semiotics framework and Kressand Van Leeuwen's (2006) model of reading images to explore the representation of genders in Iran Language Institute textbooks and found that verbal and visual elements interact with each other and portray females as invisible and underrepresented in the textbooks analyzed. In the same year, in a textbook evaluation study through a questionnaire, Jamalvandi (2014) reported on teachers' views on the newly published Iranian pre-university ELT textbook, and discovered that $36 \%$ of the teacher participants postulated that the book illustrated a balanced view of both genders, and only $13.3 \%$ of the respondents believed in underrepresentation of females. Correspondingly, Ebrahimi (2015) examined gender bias in Volumes 2 and 3 of the Persian language textbooks Let's Learn Persian taught at intermediate level to children in Persian language centers across the world. The results of the study showed that the analyzed textbooks were significantly unbalanced in gender representation both in the texts and illustrations, and that such a representation did not echo the significant roles females play roles in the Iranian society.

\section{Method}

\section{The corpus}

To analyze gender representation in Iranian ELT textbooks, all the images in Prospect 1, 2, \& 3 series provided by the Iranian Ministry of Education were selected. The textbooks were written by a panel of applied linguists and published in 2013. The 3 textbooks are taught nation-wide to high school students during 3 years. The package also includes student's books, workbooks, teacher's books, Audio CDs, and teacher's flashcards, not all of which are accessible to all teachers and students in different parts of Iran. As a deep-seated variation from the preceding series, such textbooks are quite recent and are, therefore, subject to analysis and evaluation. Hence, they were chosen to be investigated in this study.

\section{Methodological Framework}

A converged methodological framework was developed by congregating principles and criteria presented in Goffman's (1979) content analysis of gender representation, which take such aspects as narrative role, gaze direction, distance, body display, and space into account, as well as Kress and van Leeuwen's (2006) social semiological analysis model, which highlights the objective formal relationships and a rich analysis of texts. The images were analyzed vis-à-vis five main questions, each of which comprised of some subcategories. The main questions were: 1) Who is active in the image? 2) Where is the gaze directed at? 3) What is the role of visual technique in representing the gender? 4) What does the clothing communicate? and 5) What are the frequent spaces in which the two genders are presented?

Trying to answer the first question and using Goffman's (1979) terminologies, the 
participants in the textbooks images were analyzed so as to find if they played any of the following four roles: a) the 'actor role', where they really do something to another participant in the image, b) the 'goal role', which they become the receiver of another participant's action, c) the 'behaver' role, in which they perform such non-transitive actions as feeling or smiling, and d) the 'reactor' role to an object or a situation. To analyze where the gaze (eye-direction) were directed at, Goffman's (1979) model was used to detect two kinds of gazes in the images: 1) the participant(s) in the image gaze at the viewer, and 2) the participants in the image gaze away from the viewer. Regarding the third question and following Kress and van Leeuwen's (2006) model, 3 subcategories were set forth to analyze the role of visual techniques in representing the gender in the images: a) close-up, i.e. where the camera provides the magnified view of the participants in the image, b) medium shot, where there is an equal distance between the participants and the space around them in the image, and c) long shotwhere the participants are seen from a public distance in the textbooks images. In order to find out what the clothing of males and females communicated in the images, the types of the clothes the participants wore in the textbooks images were divided into three subcategories of scantily clothed (e.g. wearing shorts), partially clothed (wearing T- shirts or tops), and fully clothed (wearing business suits, scarfs, and chadors). Finally, a set of places like homes, streets and neighborhoods, leisure areas, workplaces, and shops were detected to analyze in what frequent spaces the two genders are presented in the images of the 3 textbooks.

\section{Procedure}

Analyzing the main questions and their subcategories, this study utilized content analysis to find out how the two genders are represented the images of textbooks Prospect 1, 2, \& 3. Ary, Jacobs, Irvine, and Walker (2019) define content analysis as a "search method applied to written or visual materials for the purpose of identifying specified characteristics of the material or meaning inferred from the material. The materials analyzed can be textbooks, newspapers, web pages, social network sites, twitter feeds, blogs, virtual worlds, speeches, television programs, advertisements, musical compositions, or any of a host of other types of documentation" (p.414). Accordingly, all of the images of the Prospect series' student's books and workbooks were analytically examined. The frequencies with which each of the subcategories of the main questions were detected in the textbooks images were tabulated and converted to percentages. Using IBM SPSS version 23, Chi-Square analysis was run to determine whether there was a significant difference between the two genders for each main question. Another rater was deliberately chosen to rate and tabulate the frequencies of the textbooks images apropos the subcategories in each main question. Inter-rater reliability of the collected data was then calculated via Cohen's Kappa coefficient $(\kappa=0.89)$ using the IBM SPSS version 23, indicating a near perfect agreement between the raters.

\section{Results and Discussion}

The results of the study are interpreted and discussed in this section to analytically investigate 
gender representation in the images illustrated in the Iranian ELT textbooks Prospect 1, 2, \& 3. Each main question and its subcategories are discussed in detail and juxtaposed with other studies' findings to spot any similarities or contrasts between the findings of this project and those of other studies.

\section{Who is Active in the Image?}

The frequencies and the percentages of the roles of the participants in the images of the Prospect Series based on their genders are displayed in Table 1.

Table 1

The Roles of the Participants based on the Genders in Prospect series Images (\%)

\begin{tabular}{lcc|cc|cc}
\hline & \multicolumn{2}{c|}{ Prospect 1 } & \multicolumn{2}{c|}{ Prospect 2 } & \multicolumn{2}{c}{ Prospect 3 } \\
\cline { 2 - 7 } & $\underline{M(\%)}$ & $\underline{F(\%)}$ & $\underline{M(\%)}$ & $\underline{F(\%)}$ & $\underline{M(\%)}$ & $\underline{F(\%)}$ \\
Actor & $29(50.88)$ & $9(27.28)$ & $33(52.38)$ & $5(35.71)$ & $38(48.71)$ & $10(28.57)$ \\
Goal & $3(5.27)$ & $6(18.18)$ & $4(6.35)$ & $3(21.43)$ & $3(3.85)$ & $6(17.14)$ \\
Behaver & $23(40.35)$ & $15(45.45)$ & $23(36.50)$ & $5(35.71)$ & $36(46.15)$ & $19(54.29)$ \\
Reactor & $2(3.50)$ & $3(9.1)$ & $3(4.76)$ & $1(7.15)$ & $1(1.28)$ & $0(0)$ \\
Total & $57(100)$ & $33(100)$ & $63(100)$ & $14(100)$ & $78(100)$ & $35(100)$ \\
\hline
\end{tabular}

As can be seen in Table 1, in more than half (50.88\%) of the images of Prospect 1 males played an active role in the images while females were active in only $27.28 \%$ of the cases. Such a trend is also observed in Prospect 2 (with $52.38 \%$ male actors and $35.71 \%$ female actors) and Prospect 3 (with $48.71 \%$ of male actors and $28.57 \%$ female actors in the images of the textbook). In general, the percentage of males playing an active role in the images is roughly 1.5 times more than that of females. Females were also portrayed as the goal of the other participants' actions in the images of the textbooks approximately four times as many as males, among which Prospect 2 showed the most discrimination among the genders with females being the goal of other peoples' actions in $21.43 \%$ of the cases and males in $6.35 \%$ of the cases. Yet, both males and females played a rather equal behaver role in the images of the textbooks analyzed with the exceptions of Prospect 3 where women $(54.29 \%)$ performed such non-transitive actions as feeling or smiling more than men (46.15\%). Additionally, while 9.1\% of the females in the images of Prospect 1 (almost 1.5 times more than males) performed a reactor role to an object or a situation, $7.15 \%$ of the females in the images of Prospect 2 (almost 2.5 times more than males) perfumed such a role. Surprisingly, in none of the images in Prospect 3, females were depicted as reactors.

Table 2 presents the results of Chi-Square analysis for the roles of the participants in the images of the Prospect Series. 
Table 2

Chi-Square Analysis for the Roles of the Participants in Prospect Series Images

\begin{tabular}{lc|c|c}
\hline & Prospect 1 & Prospect 2 & Prospect 3 \\
\hline Chi-Square & $6.400^{\mathrm{a}}$ & $31.182^{\mathrm{b}}$ & $16.363^{\mathrm{c}}$ \\
df & 1 & 1 & 1 \\
Asymp. Sig. & .011 & .000 & .000 \\
\hline
\end{tabular}

a. 0 cells $(.0 \%)$ have expected frequencies less than 5 . The minimum expected cell frequency is 45.0 .

b. 0 cells $(.0 \%)$ have expected frequencies less than 5 . The minimum expected cell frequency is 38.5 .

c. 0 cells $(.0 \%)$ have expected frequencies less than 5 . The minimum expected cell frequency is 56.5 .

Based on these results of the Chi-square analysis in Table 2 (Prospect 1, $\chi^{2}=0.011$; Prospect 2, $\chi^{2}=0.00$; and Prospect 3, $\left.\chi^{2}=0.00 ; d f=1, \mathrm{p}<.005\right)$, it appears that such a gender representation in the pictures of the analyzed textbooks was statistically significant, and we can be $95 \%$ confident that there is some sort of gender bias in terms of the roles both sexes played in the images of the analyzed textbooks. Portraying the males as having an overriding power and females as submissive and weak is an aspect that is also observed in other studies investigating other textbooks, both in international and other countries' ELT textbooks (Amerian \& Esmaili, 2015; Giaschi, 2000; Gholami \& Arashlou, 2014; Mukundan \& Nimehchisalem, 2008; Skelton, 1997; Stockdale, 2006), and in Iranian textbooks (Ansary \& Babaii, 2003; Ebrahimi, 2015; Fatemi et al., 2011; Marefat \& Marzban, 2014; Paivandi, 2008). However, such results contradict the findings of a few studies (Healy, 2009; Lee \& Collins, 2009; Liao \& Huang, 2003; Mineshima, 2008) which reported an egalitarian representation of the genders in the textbooks they investigated.

\section{Where is the Gaze Directed?}

Another aspect of the textbook images was where the gaze (eye-direction) were directed at. The participants in the images looked either at or away from the viewer. The angle of eye direction of the participants in the images of the 3 textbooks for each gender is illustrated in Table 3.

Table 3

The Eye Direction of the Participants Based on the Genders in Prospect Series Images (\%)

\begin{tabular}{|c|c|c|c|c|c|c|}
\hline \multirow{2}{*}{ Subcategories } & \multicolumn{2}{|c|}{ Prospect 1} & \multicolumn{2}{|c|}{ Prospect 2} & \multicolumn{2}{|c|}{ Prospect 3} \\
\hline & $M(\%)$ & $F(\%)$ & $M(\%)$ & $F(\%)$ & $M(\%)$ & $F(\%)$ \\
\hline At the viewer & $23(41.81)$ & $5(20.84)$ & $9(16.07)$ & $0(0)$ & 18 (20.69) & $3(10.35)$ \\
\hline $\begin{array}{l}\text { Away from the } \\
\text { viewer }\end{array}$ & $32(58.18)$ & $19(79.17)$ & 47 (83.93) & $12(100)$ & $69(73.31)$ & $26(89.66)$ \\
\hline Total & $55(100)$ & $24(100)$ & $56(100)$ & $12(100)$ & $87(100)$ & $29(100)$ \\
\hline
\end{tabular}


As illustrated in Table 3, in all of the 3 textbooks analyzed, most women in the pictures gazed away from the viewer; that is, only 5 (out of 24) of the female participants in the images of Prospect 1, and 3 (out of 29) of the female participants in the images of Prospect 3 were gazing at the viewer. The most discriminated case, however, was observed in Prospect 2, in which none of the 12 female participants in the images ever looked at the viewer. Besides, according to the results of Chi-Square analysis (see Table 4) for the eye direction of the participants in the images of the Prospect Series (Prospect 1, $\chi^{2}=0.00 ;$ Prospect 2, $\chi^{2}=0.00$; and Prospect 3, $\left.\chi^{2}=0.00 ; d f=1, \mathrm{p}<.005\right)$, one can $95 \%$ confidently resolve that there is some kind of gender discrimination in representing the eye directions of the sexes in the images of the analyzed textbooks.

Table 4

Chi-Square Analysis for the Gazes of the Participants in Prospect Series Images

\begin{tabular}{lc|c|c} 
& Prospect 1 & Prospect 2 & Prospect 3 \\
\hline Chi-Square & $12.165^{\mathrm{a}}$ & $28.471^{\mathrm{b}}$ & $29.000^{\mathrm{c}}$ \\
$\mathrm{df}$ & 1 & 1 & 1 \\
Asymp. Sig. & .000 & .000 & .000 \\
\hline
\end{tabular}

a. 0 cells $(.0 \%)$ have expected frequencies less than 5 . The minimum expected cell frequency is 39.5 .

b. 0 cells $(.0 \%)$ have expected frequencies less than 5 . The minimum expected cell frequency is 34.0 .

c. 0 cells $(.0 \%)$ have expected frequencies less than 5 . The minimum expected cell frequency is 58.0 .

Regarding the gaze patterns in the pictures, Goffman (1976) maintains that the gaze (eyedirection) of the participants can divulge the ideology behind the gender representation in the images. And, Giaschi (2000), in the same vein, remarked that "it seems opportune to make clear and available to ESL teachers how ideologies are being packed and presented to them [teachers] and how they themselves may be positioned" (p.35). It appears that the authors of the textbooks and/or the Iranian Ministry of Educations, which initiated, funded, and supervised the textbooks development, considered females' gazing at the viewer to be against the Islamic regulations prevailing in the country, and decided to include just a few of such gazes in nation-wide textbooks. However, Benjamin (2015, p.30), describing ELT materials in the Middle East, believes that "the phrase 'culturally appropriate' often means that the materials do not risk offending Islamic beliefs" while "middle Eastern learners have other shared interests and activities, and are proud of their heritage and national treasures just as any other group of learners would be. In short, delivering culturally appropriate ELT classes to Muslims involves realizing and embracing the fact that they enjoy a rich and diverse culture alongside Islam" (ibid.). It appears such a clear fact had not been taken into account by the Prospect Series authors and/or the Iranian Ministry of Education.

\section{What is the Role of Visual Technique in Representing the Gender?}

Table 5 shows percentages of males and females in close-up, medium shot, and long shot frames of the images in Prospect series textbooks. In all the 3 analyzed textbooks, males were 
depicted in close-up frames much more than females who were typically portrayed in medium shot frames. The only exception, however, is Prospect 3 in which the percentages of the males $(37.15 \%)$ and females (33.34\%) illustrated in medium shots are near each other. Moreover, in Prospect 2, none of the females are imaged in close-up frames. Taking long-shots into account, although in Prospect 1 there are more males (17.54\%) than females (13.64\%) depicted in long shot frames, in the other two textbooks, more percentage of women $(50 \%$ in Prospect 2 and $60.6 \%$ in Prospect 3) are imaged in the longshots.

Table 5

The Distance of the Participants based on the Genders in Prospect Series Images (\%)

\begin{tabular}{lcc|cc|cc}
\hline & \multicolumn{2}{c|}{ Prospect1 } & \multicolumn{2}{c}{ Prospect2 } & \multicolumn{2}{c}{ Prospect 3 } \\
\cline { 2 - 6 } & $\underline{M(\%)}$ & $\frac{F(\%)}{6(27.28)}$ & $\frac{M(\%)}{24(35.3)}$ & $\frac{F(\%)}{0(0)}$ & $\frac{M(\%)}{13(18.57)}$ & $2(6.06)$ \\
Close-up & $18(31.58)$ & $6(\%)$ & $5(50)$ & $26(37.15)$ & $11(33.34)$ \\
Medium Shot & $29(50.88)$ & $13(59.1)$ & $28(41.18)$ & $5(50)$ & $31(44.29)$ & $20(60.6)$ \\
Long Shot & $10(17.54)$ & $3(13.64)$ & $16(23.53)$ & $5(10)$ & $70(100)$ & $33(100)$ \\
Total & $57(100)$ & $22(100)$ & $68(100)$ & $10(100)$ & & \\
\hline
\end{tabular}

The results of Chi-Square analysis for the distance of the participants in the images of the Prospect Series are displayed in Table 6. Based on these results of the Chi-square analysis in Table 6 (Prospect 1, $\chi^{2}=0.00$; Prospect 2, $\chi^{2}=0.00$; and Prospect $3, \chi^{2}=0.00 ; d f=1, \mathrm{p}<.005$ ), it seems that such a gender representation in the pictures of the analyzed textbooks was statistically significant, and we can agree that there is some sort of gender bias in terms of the distance between the genders depicted in the images of the analyzed textbooks.

Table 6

Chi-Square Analysis for the Distance of the Participants in Prospect Series Images

\begin{tabular}{lc|c|c}
\hline & Prospect 1 & Prospect 2 & Prospect 3 \\
\hline Chi-Square & $15.506^{\mathrm{a}}$ & $43.128^{\mathrm{b}}$ & $13.291^{\mathrm{c}}$ \\
df & 1 & 1 & 1 \\
Asymp. Sig. & .000 & .000 & .000
\end{tabular}

a. 0 cells $(.0 \%)$ have expected frequencies less than 5 . The minimum expected cell frequency is 39.5 .

b. 0 cells $(.0 \%)$ have expected frequencies less than 5 . The minimum expected cell frequency is 39.0 .

c. 0 cells $(.0 \%)$ have expected frequencies less than 5 . The minimum expected cell frequency is 51.5 .

According to Kress and van Leeuwen (2006), the social distance between the viewer and the participants of the image can be affected by the distance between the participants in the frames and the situation of the images. Considering that most of the female characters are portrayed in medium and long shots in the images of the Prospect series, one can argue that the authors of Prospect Series and/or the Iranian Ministry of Education had, intentionally or unintentionally, developed a kind of social distance between the viewers and the female characters, the reason for which can reside in the ideologies of the authors or in those of the authorities at Iranian Ministry of Education. 


\section{What does the Clothing Communicate?}

In Table 7, the frequency of clothing types of the participants in the images of the Prospect Series textbooks are provided based on the gender of the participants and in terms the kind of clothes they were wearing; i.e. whether the male and female participants in the images were scantily clothed, partially clothed, or fully clothed.

Table 7

The Clothing of the Participants based on the Genders in Prospect Series Images (\%)

\begin{tabular}{lcc|cc|cc}
\hline \multirow{2}{*}{ Subcategories } & \multicolumn{2}{c|}{ Prospect 1 } & \multicolumn{2}{c|}{ Prospect 2 } & \multicolumn{2}{c}{ Prospect 3 } \\
\cline { 2 - 7 } & $\frac{M(\%)}{1(2)}$ & $\frac{F(\%)}{0(0)}$ & $\frac{M(\%)}{3(6)}$ & $\frac{F(\%)}{0(0)}$ & $\frac{M(\%)}{0(0)}$ & $\frac{F(\%)}{0(0)}$ \\
Scantily Clothed & $17(34)$ & $0(0)$ & $19(38)$ & $0(0)$ & $13(17.34)$ & $0(0)$ \\
Partially Clothed & $32(64)$ & $23(100)$ & $28(56)$ & $11(100)$ & $62(83.67)$ & $35(100)$ \\
Fully Clothed & $50(100)$ & $23(100)$ & $50(100)$ & $11(100)$ & $75(100)$ & $35(100)$ \\
Total & \multicolumn{3}{c}{}
\end{tabular}

Table 7 indicates that most of the males' and females' images (78.27\%) and all of the females' images were depicted as fully clothed in the analyzed textbooks. As Paivandi (2008) puts it, such gender representations in terms of clothing may be due to the fact that in some Islamic countries like Iran, women have to wear a clothing norm called hijab in which they are supposed to fully cover their hair, necks, and bodies. Such a clothing norm is also found in males' images in Prospect Series, where men are rarely scantily clothed (only in 4 images out of the 244 of images in all the 3 textbooks).

Table 8

Chi-Square Analysis for the Clothing of the Participants in Prospect Series Images

\begin{tabular}{lc|c|c}
\hline & Prospect1 & Prospect2 & Prospect 3 \\
\hline Chi-Square & $9.986^{\mathrm{a}}$ & $24.934^{\mathrm{b}}$ & $14.545^{\mathrm{c}}$ \\
df & 1 & 1 & 1 \\
Asymp. Sig. & .002 & .000 & .000 \\
\hline
\end{tabular}

a. 0 cells $(.0 \%)$ have expected frequencies less than 5 . The minimum expected cell frequency is 36.5 .

b. 0 cells $(.0 \%)$ have expected frequencies less than 5 . The minimum expected cell frequency is 30.5 .

c. 0 cells $(.0 \%)$ have expected frequencies less than 5 . The minimum expected cell frequency is 55.0.

Based on these results of the Chi-square analysis in Table 8 (Prospect 1, $\chi^{2}=0.002$; Prospect 2, $\chi^{2}=0.00$; and Prospect 3, $\left.\chi^{2}=0.00 ; d f=1, \mathrm{p}<.005\right)$, it appears that such a gender representation in the pictures of the analyzed textbooks was statistically significant, and we can be $95 \%$ confident that there is some kind of gender bias in terms of the types of clothes both sexes wore in the images of the 3 analyzed textbooks. It seems quite evident that clothing of a person may carry special meanings regarding his/her social status, occupation, personality, and religious and cultural beliefs. Moreover, as to Kress \& van Leeuwen (2006), some believe that 
representing females clothed scantily or even partially may place them as objects to be observed, desired and possessed. Based on the results indicated in Tables 7 and 8, one may argue that the authors of the Prospect series firmly believed in such a notion, which is of course consistent with the religious beliefs and cultural values of the majority of the religious people in Iran. This, according to Tomlinson (2017), can be considered a positive point of the books in this regard since he believes that local and national cultural values should be taken into consideration before, while, and after the development of textbooks and throughout their evaluation.

\section{What are the Frequent Spaces in which the Two Genders are Presented?}

A set of places like homes, work places, streets and neighborhoods, leisure areas, and shops are shown in Table 9 in order to analyze in what frequent spaces the two genders were presented in the images of the Prospect 1, 2, and 3 textbooks. The location participants are portrayed in the images of the textbooks is referred to as space, which can be indoor or outdoor.

Table 9

The Frequent Space of the Participants based on the Genders in Prospect Series Images (\%)

\begin{tabular}{lcc|cc|cc}
\hline \multirow{2}{*}{ Subcategories } & \multicolumn{2}{c|}{ Prospect 1 } & \multicolumn{2}{c}{ Prospect 2 } & \multicolumn{2}{c}{ Prospect 3 } \\
\cline { 2 - 6 } & $\underline{M(\%)}$ & $\underline{F(\%)}$ & $\underline{M(\%)}$ & $\underline{F(\%)}$ & $\underline{M(\%)}$ & $\underline{F(\%)}$ \\
Home & $4(9.75)$ & $3(20)$ & $1(2.04)$ & $2(15.38)$ & $6(10.71)$ & $4(12.9)$ \\
Workplace & $21(51.21)$ & $9(60)$ & $14(28.57)$ & $6(46.15)$ & $29(51.79)$ & $16(51.61)$ \\
Street/ Neighborhood & $11(26.83)$ & $0(0)$ & $12(24.48)$ & $3(23.07)$ & $16(28.57)$ & $8(25.8)$ \\
Leisure & $2(4.87)$ & $1(6.67)$ & $22(44.9)$ & $2(15.38)$ & $4(7.14)$ & $3(9.67)$ \\
Shop & $3(7.32)$ & $2(13.34)$ & $0(0)$ & $0(0)$ & $1(1.78)$ & $0(0)$ \\
Total & $41(100)$ & $15(100)$ & $49(100)$ & $13(100)$ & $56(100)$ & $31(100)$ \\
\hline
\end{tabular}

Looking carefully at table 9, one can come across the fact that while females were depicted more in indoor spaces in the images of the all the three textbooks, males were rarely represented in such spaces. That is, in $20 \%$ of the images of Prospect 1, $15.38 \%$ of the Prospect 2, and $12.9 \%$ of the images in Prospect 3, women are illustrated at home whereas men were depicted at home in only 9.75\%, 2.04\%, and 10.71\% of the images in Prospect 1, 2, and 3 , respectively. Males also appeared more in such outdoor spaces as street and neighborhoods. Nevertheless, female characters - with $60 \%$ in Prospect 1 , and $46.15 \%$ in Prospect 2 outnumbered male ones in workplace spaces, and had a rather equal presence in the images of Prospect 3 (with 51.61\%, as opposed to men's presence with 51.79\%). Moreover, despite the fact that Prospect 1 (in 6.67\% of the images) and Prospect 3 (in $9.67 \%$ of the images) illustrated women more than men in leisure spaces, Prospect 2 depicts less women (with $15.38 \%$, as opposed to men with $44.9 \%$ ) in such places. As for shopping places, however, to the researcher's surprise, no men and women were shown in the shops in the images of the textbook Prospect 2. This is while more women $(13.34 \%>7.32 \%)$ were portrayed in shopping 
spaces than men in Prospect 1. On the contrary, while no females were depicted in the shops in the images of Prospect 3, and $1.78 \%$ of men in the same book were presented in the shops.

Furthermore, according to the results of Chi-Square analysis (see Table 10) for the place in which the participants in the images of the Prospect Series appeared (Prospect 1, $\chi^{2}=0.01$; Prospect 2, $\chi^{2}=0.00$; and Prospect 3, $\chi^{2}=0.00 ; d f=1, \mathrm{p}<.005$ ), one can 95\% confidently arrive at the decision that the obtained data are statistically significant.

Table 10

Chi-Square Analysis for the Places of the Participants in Prospect Series Images

\begin{tabular}{lc|c|c} 
& Prospect1 & Prospect2 & Prospect 3 \\
\hline Chi-Square & $12.071^{\mathrm{a}}$ & $20.903^{\mathrm{b}}$ & $7.184^{\mathrm{c}}$ \\
df & 1 & 1 & 1 \\
Asymp. Sig. & .001 & .000 & .007 \\
\hline
\end{tabular}

a. 0 cells $(.0 \%)$ have expected frequencies less than 5 . The minimum expected cell frequency is 28.0 .

b. 0 cells $(.0 \%)$ have expected frequencies less than 5 . The minimum expected cell frequency is 31.0 .

c. 0 cells $(.0 \%)$ have expected frequencies less than 5 . The minimum expected cell frequency is 43.5 .

The results of the study specified that the authors of the textbooks, again intentionally or unintentionally, have presented a rather balanced image of women, particularly in spaces like workplace in the images of all the 3 textbooks and in the leisure-related spaces in Prospect 1 and Prospect 3. Such a representation of genders indicates that women, just like men, can appear in both leisure-related areas and such spaces as workplace which demands more power, dominance, and social status. These findings are in line with a few previous studies (Healy, 2009; Lee \& Collins, 2009; Liao \& Huang, 2003; Mineshima, 2008) which reported an egalitarian representation of the genders in the textbooks they investigated, and in contradiction of numerous other studies which reported a dearth of women in work- and leisure-related images (Hamdan \& Jalabneh, 2009; Lee, 2006; Levine \& O'Sullivan, 2010; Nakamura, 2002; Porreca, 1984; Roohani \& Zarei, 2013). The findings are also in proportion to Richards (2014) who accentuates how sensitive materials developers should be to "maintaining a 50-50 balance between the sexes: numerically and in terms of the significance and prominence of the activity illustrated; within schools and across the series, to aim for a gender-neutral style of illustration; to use illustrations that include all physical types, with occasional evidence of physical disability; and to avoid images with a stereotypical association" (p. 27). Moreover, such a balanced portrayal of men and women in the images in both indoor and outdoor activities is consistent with the significant social roles both men and women play in the Iranian society. Notwithstanding, we observed that females appeared less than males on streets and in neighborhoods of the images in all of the analyzed textbooks. This can be attributable to the Islamic culture and beliefs dominant in Iran which indoctrinate the belief that it is favored for women to stay at closed spaces like homes, workplace, and shops rather than being present at such open spaces as streets and neighborhoods. 


\section{Conclusion}

The present study tried to examine gender representation in the images of the newly designed and published nation-wide ELT textbooks in Iran called Prospect 1, 2, and 3. Developing a converged framework by utilizing the principles and criteria presented for image analysis in Goffman (1979) and Kress \& van Leeuwen's (2006), the roles of both sexes in the pictures of the textbooks were analyzed in terms of active role, gaze direction, visual techniques, distance, and space. The statistically significant results of the study demonstrated that in the images of the analyzed textbooks, males were depicted as playing a more active role and females were mostly portrayed as the reactive and goal participants. Also, the analysis of gaze direction revealed that males were frequently imaged as looking at the viewer while females were mainly illustrated as looking away from the viewer. Likewise, although women were typically shown in long shot frames - which expands the social distance between the participants in the images and the viewers of the images, men were frequently depicted in close-up frames which implied their prominence. In contrast, on the subject of clothing, both males and females were portrayed as fully clothed in virtually all pictures of the textbooks with the exception some men who were imaged as partially clothed in some cases. Conversely, women were never represented scantily or partially clothed. Such a representation of genders in the Prospect Series textbook was discussed to be in accordance with the Islamic beliefs and culture dominant in Iran. Concerning the places in which both sexes were portrayed in the images of the textbooks, it was shown that the authors illustrated a rather balanced view towards both males and females.

Taking the findings of the study into consideration, we can set forth a number of pedagogical implications. First and foremost, the Iranian government, and the Ministry of Education in particular, can instigate a program to promote gender equality in educational materials via developing some unbiased ELT materials in which women are depicted in every role and situation men can be in the real world. Second, some gender equality consciousnessraising courses can be conducted for both learners and teachers so as to expose them to the negative aspects of gender bias, which can eventually help both teachers and learners adapt the gender-biased materials they encounter in the textbooks. Moreover, the Iranian Ministry of Education can carry out a nation-wide survey on a representative sample of the stakeholders in materials development in order to find out what they need, want, and believe regarding the images in the textbooks. Considering the findings of this study, it is recommended that some other studies be conducted to investigate gender representation in Prospect Series dialogues, reading passages, adjectives used to describe each gender, and the amount and type of talk each gender uses throughout the book. It is also suggested that some evaluative studies be carried out to find out teachers' and learners' opinions on the images of the Prospect Series textbooks.

\section{References}


Alemi, M., \& Jafari, H. (2012). Gender and culture analysis in ELT textbooks as measured by personal proper names. Advances in Asian Social Science, 1(2), 237-243.

Alrabaa, S. (1985). Sex division of labour in Syrian school textbooks. International Review of Education, 31(1), 335-348. https://doi.org/10.1007/BF02262586

Amerian, M., \& Esmaili, F. (2015). Language and gender: A critical discourse analysis on gender representation in a series of international ELT textbooks. International Journal of Research Studies in Education, 4(2), 312. https://doi.org/10.5861/ijrse.2014.963

Ansary, H., \& Babaii, E. (2003). Subliminal sexism in current ESL/ELT textbooks. Asian ELT Journal, 5(1), 200241.

Ary, D., Jacobs, L. C., Irvine, C. K. S., \& Walker, D. (2019). Introduction to research in education. Cengage Learning.

Atay, M., \& Danju, I. (2012). Analysis of 1st grade and 5th grade textbooks and primary school students' views about personal traits in gender role in society. Social and Behavioral Sciences, 47, 64-73. https://doi.org/10.1016/j.sbspro.2012.06.614

Bahman, M., \& Rahimi, A. (2010). Gender representation in ELT materials: An analysis of English textbooks of Iranian high schools. Social and Behavioral Sciences, 9, 273-277. https://doi.org/10.1016/j.sbspro.2010.12.149

Benjamin, P. (2015). Cultural appropriacy in materials adaptation: Do we need to walk on eggshells? Folio, 16(2), 30-35.

Birjandi, P. \& Amini, M. (2012). Gender bias in the Iranian high school ELT textbooks. English Language Teaching, 5(2), 134-147. https://doi.org/10.5539/elt.v5n2p134

Blumberg, R. L. (2007). Gender Bias in Textbooks: A Hidden Obstacle on the Road to Gender Equality in Education. Paris: UNESCO.

Cameron, D. (1998). Is there any ketchup, vera: Gender, power and pragmatics. Discourse \& Society, 9(4), 437455. https://doi.org/10.1177/0957926598009004002

Chick, K. A. (2006). Gender Balance in K-12 American History Textbooks. Social Studies Research and Practice, 1(3), 284-290.

Christie, C. (2000). Gender and language: Towards a feminist pragmatics. Edinburgh: Edinburgh University Press.

Cortazzi, M., \& Jin, L. (1999). Cultural mirrors: Materials and methods in the ELT classroom. In

E. Hinkel (Ed.), Culture in second language teaching and learning (pp. 196-219). Cambridge: Cambridge University Press.

Crabb, P. B., \& Bielawski, D. (1994). The social representation of material culture and gender in children's books. Sex roles, 30(1-2), 69-79. https://doi.org/10.1007/BF01420740

Cunningham, M. (2008). Influences of gender ideology and housework allocation on women's employment over the life course. Social Science Research, 37(1), 254-267. https://doi.org/10.1016/j.ssresearch.2007.01.003

del-Teso-Craviotto, M. (2006). Words that matter: Lexical choice and gender ideologies in women's magazines. Journal of Pragmatics, 38(11), 2003-2021. https://doi.org/10.1016/j.pragma.2005.03.012

Dominguez, L. M. (2003). Gender textbook evaluation. A paper submitted to CELS as Course Requirement for the Degree of Master of Arts in Teaching English as a Second Language (TESL/TELT). University of Birmingham, United Kingdom.

Ebrahimi, B. (2015). Gender Representation in the Textbooks of Teaching Persian to Speakers of Other Languages. Journal of Applied Linguistics and Language Research, 2, 143-157.

Erden, F. T. (2009). A course on gender equity in education: Does it affect gender role attitudes of preservice teachers? Teaching and Teacher Education, 25(3), 409-414. https://doi.org/10.1016/j.tate.2008.11.001 
Fairclough, N. (1989). Language and Power. London: Longman.

Fatemi, A. H., Pishghadam, R., \& Heidarian, Z. (2011). Gender Delineation in High school and Pre-university ELT Textbooks: A Criterion-Oriented Approach to Text Analysis. The Iranian ELT Journal, 7(3), 32-47.

Gershuny, H. L. (1977). Sexism in dictionaries and texts: Omissions and commissions. In Nilsen, A., Bosmajian, H., Gershuny, H. \& Stanley J. (Eds.), Sexism and language (pp. 143-160). Urbana, IL: National Council of Teachers of English.

Gharbavi, A., \& Mousavi, S. A. (2012). A content analysis of textbooks: Investigating gender bias as a social prominence in Iranian high school English textbooks. English Linguistics Research, 1(1), 42-49. https://doi.org/10.5430/elr.v1n1p42

Gholami, J., \& Arashlou, S. A. (2014). A comparative study of gender representation in ELT textbooks. In Ç. T. Mart (Ed.), Book of Proceedings. 5th International Visible Conference on Foreign Language Teaching and Applied Linguistics (pp. 446-462). Iraq: Erbil.

Giaschi ,P. (2000). Gender Positioning in Education: A Critical Image Analysis of ESL Texts. TESL Canada Journal, 18(1), 32-46. https://doi.org/10.18806/tesl.v18i1.898

Goffman, E. (1976). Gender advertisements. New York: Harper \& Row Publishers. https://doi.org/10.1007/9781-349-16079-2

Hamdan, S., \& Jalabneh, A. (2009). Topics in ELT textbooks and the question of gender dominance: A case study from public schools of Jordan. The International Journal of Language Society and Culture, 28, 52-56.

Hartman, P. L., \& Judd, E. L. (1978). Sexism and TESOL materials. TESOL Quarterly, 12(4), $383-393$. https://doi.org/10.2307/3586137

Harwood, N. (Ed.). (2014). English language teaching textbooks - Content, consumption, production. Besingstoke: Palgrave Macmillan. https://doi.org/10.1057/9781137276285

Healy, A. (2009). The representation of women and men in a modern ELT textbook: Are popular textbooks gender biased? Memoirs of the Osaka Institute of Technology, 54(2), 91-100.

Ifegbesan, A. (2010).Gender-Stereotypes Belief and Practices in the Classroom: The Nigerian Post-Primary School Teachers'. Global Journal of Human Social Science, 10(4), 29-38.

Jamalvandi, B. (2014). ELT textbooks evaluation in Iran, new insights. European Online Journal of Natural and Social Sciences. 3(4), 1068-1078.

Jassey, A. (1998). Gender in Elementary School Texts, Japan Quarterly, 45, 87-93.

Kendall, S. (2004). Framing authority: gender, face, and mitigation at a radio network. Discourse \& Society, 15(1), 55-79. https://doi.org/10.1177/0957926504038946

Kobia, J. M. (2009). Femininity and masculinity in English primary school textbooks in Kenya. The International Journal of Language Society and Culture. Retrieved November 20, 2018 from http://www.educ.utas.edu.au/users/tle/JOURNAL/28-6.pdf.

Kõzõlaslan, I. (2010). Student teachers' perceptions of gendered texts in English language textbooks. Social

$$
\text { and Behavioral Sciences, 3528-3531. }
$$
https://doi.org/10.1016/j.sbspro.2010.03.546

Kress, G., \& van Leeuwen, T. (2006). Reading images: The grammar of visual design (2 ${ }^{\text {nd }}$ ed.).

London: Routledge. https://doi.org/10.4324/9780203619728

Kuo, S. H. (2003). Involvement vs. detachment: gender differences in the use of personal pronouns in televised sports in Taiwan. Discourse Studies, 5(4), 479-494. https://doi.org/10.1177/14614456030054002

Ladegaard, J. H. (2010). 'Doing power' at work: Responding to male and female management styles in a global business corporation. Journal of Pragmatics, 43(1), 4-19. https://doi.org/10.1016/j.pragma.2010.09.006

Lakoff, R. (1973). Language and Women's Place. Language in Society, 2(1), 45-80. 
https://doi.org/10.1017/S0047404500000051

Lee, J. F. K. (2006). Gender Representation in Hong Kong English Textbooks. Retrieved November 20, 2018 from http://www.eoc.org.hk/eoc/upload/2006711112336211184.pdf.

Lee, J. F. K., \& Collins, P. (2006). Gender representation in Hong Kong English textbooks. The Hong Kong Institute of Education. The University of New South Wales, Australia.

Levine, D., \& O' Sullivan, M. (2010). Gender and images in the ELT textbook talk a lot, Starter Book, Second Edition. The Journal and Proceedings of GALE, 3, 33-42.

Liao, Y. S., \& Huang, S. H. (2003). Gender presentation in ELT textbooks children. Selected papers from the Twelfth International Symposium on English Teaching, 2, 124-134.

Marefat, F., \& Marzban, S. (2014). Multimodal analysis of gender representation in ELT textbooks: Reader's perception. https://doi.org/10.1016/j.sbspro.2014.03.521

Masuhara, H., \& Tomlinson, B. (2008). Materials for general English. In B. Tomlinson (Ed.), English Language Learning Materials: A Critical Review, (pp. 17-37). London: Continuum.

McDonough, J., Shaw, C. \& Masuhara, H. (2013). Materials and Methods in ELT: A Teacher's Guide (3 $\left.{ }^{\mathrm{rd}} \mathrm{ed}.\right)$. London: Willey-Blackwell.

McGrath, I. (2004). 'The representation of people in educational materials'. RELC Journal, 35(3): 351-8. https://doi.org/10.1177/0033688205052147

Mineshima, M. (2008). Gender representations in an ELT textbook. Bulletin of Niigata Institute of Technology, 13. Niigata Institute of Technology: Kashiwazaki City, JP. Retrieved November 20, 2018 from www.niit.ac.jp/lib/contents/kiyo/genko/13/14_MINESHIMA.pdf.

Mirza, M., Keynan, H., \& Fakhar-ud-din. (2004). Gender analysis of school curriculum and textbooks. Islamabad: UNESCO.

Mishan, F., \& Timmis, I. (2015). Materials development for TESOL. Edinburgh: Edinburgh University Press.

Mukundan, J., \& Nimehchisalem, V. (2008). Gender representation in Malaysian secondary school English language textbooks. Indonesian Journal of English Language Teaching, 4(2), 155-173.

Mukundan, J., Nimehchisalem, V., \& Hajimohammadi, H. (2011). Developing an English language textbook evaluation checklist. Contemporary Issues in Education Research, 4(6), 21-28. https://doi.org/10.19030/cier.v4i6.4383

Mutekwe, E., \& Modiba, M. (2012). An Evaluation of the Gender Sensitive Nature of Selected Textbooks in the Zimbabwean Secondary School Curriculum. Anthropologist, 14(4), 365-373. https://doi.org/10.1080/09720073.2012.11891259

Nakamura, N. (2002). Images of women in high school ELT course books. JALT National Conference, Conference Proceedings, pp. 351-355. Japan: Shizuoka.

Ohara, Y., \& Saft, S. (2003). Using conversation analysis to track gender ideologies in social interaction: toward a feminist analysis of a Japanese phone-in consultation TV program. Discourse \& Society, 14(2), 153-172. https://doi.org/10.1177/0957926503014002855

Ottley, K. (2017). Why one-size-fits-all is not fit for purpose. In B. Tomlinson (Ed.), SLA research and materials development for language learning (pp.268-279). New York: Routledge.

Oyebela, O. (2003). Gender issues in textbook development: A study of gender balance in illustrations of selected textbooks for upper primary level. ILORIN Journal of Education, 22, 1-7.

Paivandi, S. (2008). Discrimination and intolerance in Iran's textbooks. New York, NY: Freedom House Publication.

Pizzini, F. (1991). Communication hierarchies in humor: Gender differences in the obstetrical/gynaecological setting. Discourse \& Society, 2(4), 477-488. https://doi.org/10.1177/0957926591002004008 
Porreca, K. L. (1984). Sexism in current ESL textbooks. TESOL QUARTERLY, 18(4), 705-724. https://doi.org/10.2307/3586584

Riazi, A. M. (2003). What textbook evaluation schemes tell us? A study of the textbook evaluation schemes of three decades. In W.A. Renandya (Ed.), Methodology and materials design in language teaching (pp. 5263). London: FontanaPress.

Richards, J. C. (2014). The ELT textbook. In S. Garton, \& K. Graves (Eds.), International perspectives on materials in ELT (pp. 19-36). Basingstoke: Palgrave Macmillan. https://doi.org/10.1057/9781137023315_2

Roohani, A., \& Zarei, M. (2013). Evaluating gender-bias in the Iranian pre-university English textbooks. Indonesian Journal of Applied Linguistics, 3(1), 115-125. https://doi.org/10.17509/ijal.v3i1.194

Saarikivi, K. (2012). Gender representation in the Finnish ELT textbook series The News Headlines and Smart Moves. Unpublished master's thesis, University of Tampere, Finland.

Skelton, C. (1997). Revisiting gender issues in reading schemes. Education 3-13, 25(1), 37-43. https://doi.org/10.1080/03004279785200091

Skliar, O. S. (2007). Gender representation and gender bias in ELT textbooks published in the Middle East: a case study of ELT textbooks published in Turkey and Iran. Thesis submitted to the graduate school of social sciences of Middle East Technical University.

Söylemez, S. A. (2010). A study on how social gender identity is constructed in ELT course books. Social and Behavioral Sciences, 9, 747-752. https://doi.org/10.1016/j.sbspro.2010.12.228

Stockdale, D. A. (2006). Gender Representation in an ELT Textbook. Unpublished master's thesis. University of Birmingham, Birmingham, UK.

Tanaka, H., \& Fukushima, M. (2002). Gender orientations to outward appearance in Japanese conversation: a study in grammar and interaction. Discourse \& Society, 13(6), 749-765. https://doi.org/10.1177/0957926502013006755

Tiemensma, L. (2009). Visual literacy: To comics or not to comics? Promoting literacy using comics. World Library and Information Congress: $75^{\text {th }}$ IFLA General Conference and Council: Literacy and Reading and Information Literacy, 94, 1-10.

Tomlinson, B. (Ed.). (2011). Materials development in language teaching $\left(^{\text {nd }}\right.$ ed.). Cambridge: Cambridge University Press.

Tomlinson, B. (Ed.). (2017). SLA research and materials development for language learning. New York: Routledge. https://doi.org/10.4324/9781315749082

Tomlinson, B., \& Masuhara, H. (2018). The complete guide to the theory and practice of materials development for language learning. USA: Willey-Blackwell.

Visser, I. (2002). Prototypes of gender: conceptions of feminine and masculine. Women's Studies International Forum, 25(5), 529-539. https://doi.org/10.1016/S0277-5395(02)00312-6

Yi, J. (2002). A Discussion on the Reform of Elementary School Social Teaching Materials from the Angle of Gender Analysis. Chinese Education \& Society, 35(5), 63-76. https://doi.org/10.2753/CED1061$\underline{1932350563}$ 